\title{
Effect of erosion and methods for its control on the surface roughness of composite resin
}

Mariana Menezes Vaz de Queiroz ${ }^{\mathrm{a}}$, Patricia Akemi Nishitani Shibasaki ${ }^{\mathrm{a}}$, Max José Pimenta Lima ${ }^{\mathrm{b}}$, Roberto Paulo Correia de Araújo ${ }^{\mathrm{b}}$, Richard Mark Foxton ${ }^{\mathrm{c}}$ Andrea Nóbrega Cavalcantiab

\begin{abstract}
OBJECTIVE: This study evaluated the surface roughness of a nanofilled composite resin submitted to different degrees of erosion and methods of control.

METHODS: 120 cylindrical composite specimens $(6 \times 1.5 \mathrm{~mm})$ were randomly divided into four groups, according to the surface protection against the erosive challenge [negative control, topical application of fluoride, glass-ionomer sealant, resin sealant]. After the application of the respective method, specimens were divided into three subgroups $(n=10)$ : a) absence of erosive challenge; b) 9 cycles of DES-RE; c) 18 cycles of DES-RE. Surface roughness (Ra, $\mu \mathrm{m})$ was recorded and statistically analyzed (2-way Anova/Tukey).

RESULTS: The glass-ionomer sealant exhibited less rough surfaces under all the conditions. However, the average roughness was significantly higher after 18 DES-RE cycles.

CONCLUSION: Despite the potential shown by glass-ionomer sealant, it was concluded that no material prevented an increase in surface roughness of the nanofilled composite after an intense erosive challenge.
\end{abstract}

Key words: Tooth wear; Fluorine compounds; Definitive dental restoration

\section{Efeito da erosão e de métodos para seu controle sobre a rugosidade superficial da resina composta}

\section{RESUMO}

OBJETIVO: Este estudo avaliou a rugosidade superficial de uma resina composta nanoparticulada submetida a diferentes graus de erosão e a métodos para seu controle.

MÉTODOS: 120 corpos de prova cilíndricos $(6 \times 1.5 \mathrm{~mm})$ em resina composta foram aleatoriamente divididos em quatro grupos experimentais, de acordo com o método de proteção superficial [controle negativo, aplicação tópica de flúor, selante ionomérico, selante resinoso]. Após a aplicação dos respectivos métodos, os corpos de prova foram divididos em três subgrupos $(n=10)$ : a) ausência de exposição à solução simulada de ácido gástrico; b) 9 ciclos de DES-RE; c) 18 ciclos de DES-RE. Valores da rugosidade superficial (Ra, $\mu \mathrm{m})$ foram registrados e analisados estatisticamente (Anova 2-critérios/Tukey).

RESULTADOS: O selante ionomérico promoveu superfícies menos rugosas, em todas as condições experimentais testadas. Porém, todas as médias de rugosidade ficaram significativamente mais altas após 18 ciclos de DES-RE. CONCLUSÃO: Apesar do potencial demonstrado pelo selante ionomérico, conclui-se que nenhum material foi capaz de evitar o aumento de rugosidade superficial da resina composta nanoparticuladas após a maior intensidade de desafio erosivo.

Palavras-chave: Desgaste dos dentes; Compostos de flúor; Restauração dentária permanente a Dentistry Course, School of Medicine and Public Health of Bahia (BAHIANA), Salvador, Bahia, Brazil ${ }^{\mathrm{b}}$ Institute of Health Sciences, Federal University of Bahia (UFBA), Salvador, Bahia, Brazil

${ }^{c}$ Kings College London Dental Institute, King's College London, London, United Kingdom
Conflict of Interests: The authors state that there are no financial and personal conflicts of interest that could have inappropriately influenced their work.

Copyright: () 2017 de Queiroz et al licensee EDIPUCRS

This work is licensed under a Creative Commons Attribution 4.0 International License. 


\section{INTRODUCTION}

Composite resins are restorative materials, which are widely used and increasingly so for aesthetic dentistry. They can be recommended for both posterior and anterior teeth as they exhibit good esthetics and excellent mechanical properties [1]. Also, composite resin can be used as a restorative material in areas where there has been loss of dental structure, in patients who have dental erosion and whose teeth come into frequent contact with acidic substances $[1,2]$.

Acids can enter the oral cavity via extrinsic sources (i.e. acidic foods) or from intrinsic sources (i.e. gastric juice) coming from recurrent regurgitations $[3,4]$. Dental erosion caused by endogenous acids can occur at any age. Erosion caused by exposure to gastric acid does not happen in a continuous sequence but by acid contact with the tooth, generally in several daily episodes [5]. Additionally, it has already been verified that gastric juice causes more erosion than carbonated drinks, this being directly associated with a lower $\mathrm{pH}$ and titratable acidity [6].

The risk of dental erosion emphasizes the need for understanding the action of acids on restorative agents, and as such, there is still limited knowledge about their influence $[7,8]$. Resin materials are affected by chemical substances in the oral cavity, which interfere with its organic matrix, causing a softening of polymers and consequently, affecting surface properties, such as roughness [8-10]. Despite many studies showing the importance of the use of fluorides and mechanical barriers on dental surfaces exposed to erosion $[2,5,7,11-13]$, further analysis is required to study their effects on restorative materials subjected to the same process.

Analyzing the surface roughness of composite resins is important in order to predict their clinical behavior and longevity. Surfaces that become rougher after contacting with chemical substances in the oral environment exhibit a greater accumulation of the biofilm [1]. Based on this assumption, the aim of this study was to compare the surface roughness of a nanofilled composite resin subjected to different methods of surface protection against erosion caused by endogenous acid. The working hypothesis was that surface protection with either a topical application of fluoride, glass-ionomer or resin sealant would prevent an increase in surface roughness, regardless of the intensity of the erosive challenge.

\section{METHODS}

\section{Sample preparation}

One hundred and twenty cylindrical specimens of composite resin (Filtek Z350 XT A3B, 3M-ESPE, Sumaré, São Paulo, Brazil) were prepared using a stainlesssteel matrix, with a height of $1.5 \mathrm{~mm}$ and a diameter of $6 \mathrm{~mm}$.

To prepare each sample, the matrix was filled with composite resin and a strip of polyester was placed over it to accommodate the material and maintain a smooth and even surface. A weight of $500 \mathrm{~g}$ was placed over the strip for 30 seconds to force excess material outwards for removal. After this time, the surface was photo-activated using an LED light (Radii Plus $1500 \mathrm{~mW} / \mathrm{cm}^{2}$, SDI, Victoria, Australia) for 20 seconds, in direct contact with the strip. Then samples were stored in relative humidity at $37^{\circ} \mathrm{C}$ for 24 hours without any exposure to light. Different procedures of surface protection, simulated erosion and surface roughness evaluation were conducted on the surface directly exposed to the light-curing unit.

After the specimens were prepared, they were placed in polystyrene resin. The samples were polished with a polishing machine (Arotec Ind. Com. Ltd., Cotia, São Paulo, Brazil), under constant irrigation, using fine sand paper (1200 grit) (JET401 Norton, Guarulhos, São Paulo, Brazil). A final polish was performed using soft cloths and diamond pastes (3, and 1- $\mu \mathrm{m} /$ Arotec Ind. Com. Ltd.). Specimens were ultrasonically cleaned for 20 minutes using distilled water (UNIQUE Ind. Com. Ltda., São Paulo, Brazil).

The composite resin specimens were investigated for any associations between the methods of surface protection and intensity of the simulation of endogenous erosion. As such, they were randomly divided into 12 experimental groups $(\mathrm{n}=10)$ (Figure 1).

\section{Methods of surface protection}

The four methods of surface protection against the erosive challenge are described as follows:

- Negative control for surface protection: The samples were not subjected to any form of erosive challenge; they were kept in relative humidity at $37^{\circ} \mathrm{C}$.

- Topical application of fluoride: On each surface, $1 \mathrm{ml}$ of neutral $2 \% \mathrm{NaF}$ (DFL Ind. Com., Jacarepaguá, Rio de Janeiro, Brazil) was applied for 1 minute, followed by washing with distilled water in an ultrasonic bath for 2 minutes.

- Glass-ionomer sealant: Product (Clinpro XT Varnish, 3M-ESPE, Sumaré, São Paulo, Brazil) was applied according to the recommendations from the manufacturer. Initially, conditioning was carried out with 37\% phosphoric acid (Biodinâmica Quím. e Farm. Ltda., Ibiporã, Paraná, Brazil) for 15 seconds. After this, equal portions of the paste and liquid were dispensed and manipulated for 15 seconds. Straight after, a thin layer was applied to the surface of the specimens using a disposable applicator followed by photoactivation for 20 seconds with the same LED unit.

- Resin sealant: Fortify (Bisco, Schaumburg, Illinois, USA) was applied in accordance with the manufacturer's recommendations. Firstly, the surface was carefully washed with water and conditioned with $37 \%$ phosphoric acid for 15 seconds, and then it was washed with copious amounts of water for 30 seconds and completely dried. Once the surface was prepared, a thin layer of sealant was evenly applied to the surface and photoactivated for 10 seconds with the same LED unit. 


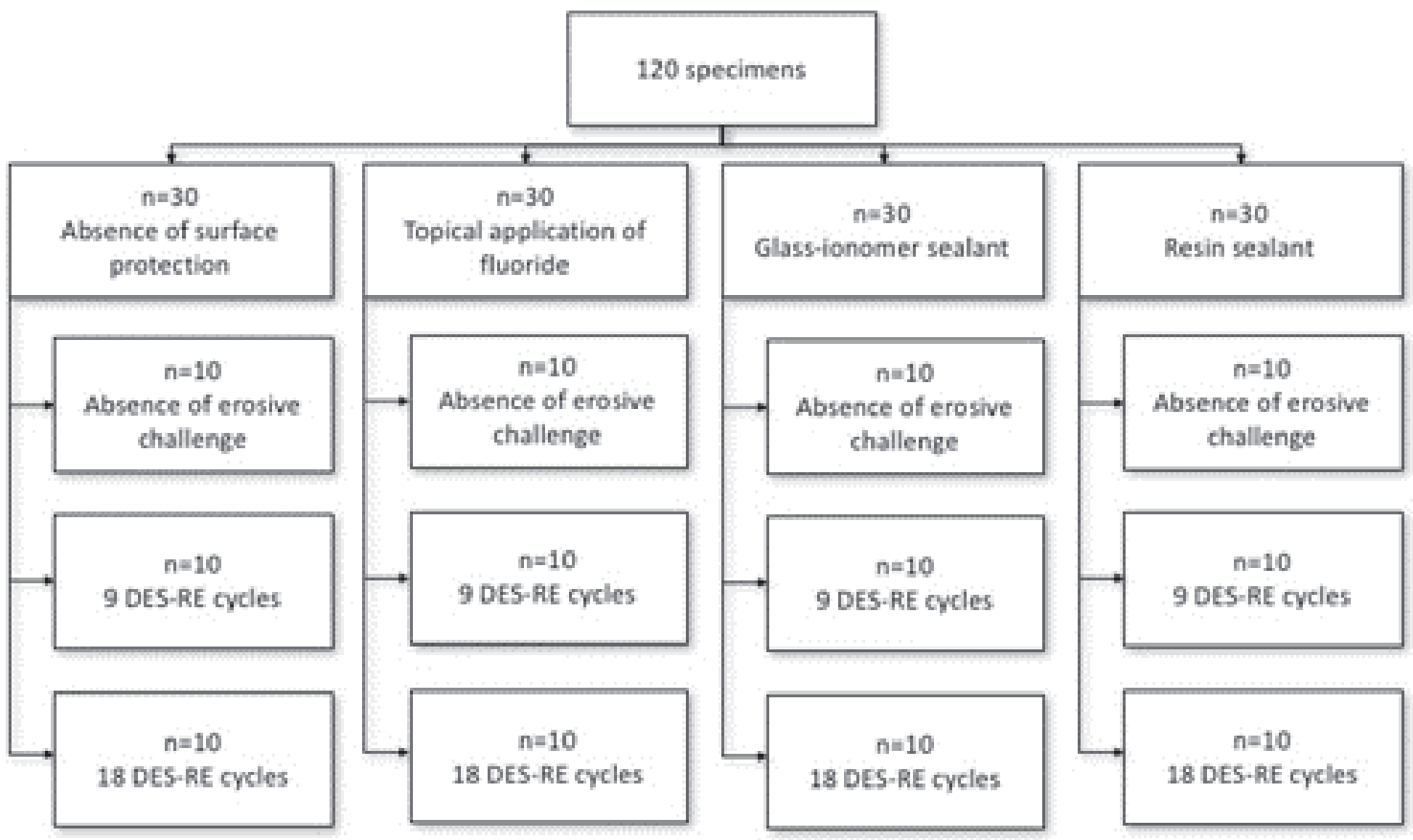

Figure 1. Distribution of the experimental groups $(n=10)$.

Table 1. Materials used and their chemical compositions.

\begin{tabular}{|c|c|}
\hline Materials (manufacturer); Lot & Chemical composition \\
\hline $\begin{array}{l}\text { Composite resin (Filtek Z350 XT A3B, 3M-ESPE, Sumaré, SP); } \\
\text { Lot } 210471\end{array}$ & $\begin{array}{l}\text { Urethane dimethacrylate, bisphenol A glycidyl methacrylate, ethoxylated } \\
\text { bisphenol A glycol dimethacrylate, triethylene glycol dimethacrylate, silica, } \\
\text { zirconia. }\end{array}$ \\
\hline $\begin{array}{l}\text { Neutral fluoride (DFL Indústria e Comércio S.A., Jacarepaguá, RJ); } \\
\text { Lot } 14121910\end{array}$ & $\begin{array}{l}\text { Sodium fluoride, sodium saccharin, cellosize qp 100, propylene glycol, } \\
\text { glycerin, mint essence and deionized water. }\end{array}$ \\
\hline $\begin{array}{l}\text { Glass-ionomer sealant (Clinpro XT Varnish, 3M-ESPE, Sumaré, SP); } \\
\text { Lot } 1331200585\end{array}$ & $\begin{array}{l}\text { Paste: 2-hydroxethylmethacrylate, bisphenol A glycidyl methacrylate, water, } \\
\text { initiators and fluoroaluminosilicate glass. } \\
\text { Liquid: polyalkenoic acid, 2-hydroxethylmethacrylate, water and initiators } \\
\text { (including camphorquinone) plus calcium glycerophosphate. }\end{array}$ \\
\hline $\begin{array}{l}\text { Resin sealant (Fortify, Bisco, Schaumburg, USA); } \\
\text { Lot } 1400003911\end{array}$ & Urethane dimethacrylate, ethoxylated bisphenol A dimethacrylate. \\
\hline
\end{tabular}

At the end of each surface protection, including the negative control, the samples were placed for seven days in relative humidity at $37^{\circ} \mathrm{C}$. Table 1 shows information related to the materials used.

\section{Simulation of erosion by gastric acid}

After using the respective method for protecting against the erosive challenge, the specimens were subdivided according to the frequency of the simulation of erosion by gastric acid $(\mathrm{n}=10)$.

- Absence of erosive challenge (control). The samples of this subgroup were kept in relative humidity of $37^{\circ} \mathrm{C}$ for 48 hours.

- 9 cycles of DES-RE: Each completed cycle consisted of immersing the sample in $10 \mathrm{ml}$ solution of hydrochloric acid $(5 \% \mathrm{HCl}, \mathrm{pH}=2.2)$ for two minutes at room temperature (DES). After this, the specimens were washed using a disposable syringe containing $20 \mathrm{ml}$ distilled water and immersed in remineralising solution (RE) for 60 minutes [adapted from 14]. The composition of the RE solution included $1.5 \mathrm{mmol} / \mathrm{L} \mathrm{Ca}, 0.9 \mathrm{mmoll} / \mathrm{L}$ PO4, $0.15 \mathrm{~mol} / \mathrm{L} \mathrm{KCl}$, and $20 \mathrm{mmol} / \mathrm{L}$ TRIS buffer at pH 7.0 and its use was based on the work of Toda and Featherstone [15].Samples from this group were exposed to 9 cycles throughout the day. Between the cycles, the units were stored in relative humidity at $37^{\circ} \mathrm{C}$.

- 18 cycles of DES-RE: the samples of this subgroup were subjected to double the frequency of cycles to promote a more aggressive challenge. Each cycle was carried out as previously described.

\section{Surface roughness}

The roughness of the surface of the top of every sample was individually evaluated with a rugosimeter, (Surftest 3000, Mitutoyo Sul Americana, São Paulo, São Paulo, Brazil). The arithmetic average between peaks and dips ( $\mathrm{Ra})$ 
was considered for each reading and it was recorded over a distance of $1.25 \mathrm{~mm}$ at a speed of $0.1 \mathrm{~mm} / \mathrm{s}$. Three readings per surface were carried out in different positions to include a greater range of area covered. The value of roughness was obtained by calculating the mean of the three readings.

The normality of the data obtained was tested using Shapiro-Wilk's test for normality. The values were analyzed by two-way ANOVA (surface protection $\times$ erosive challenge) and post-hoc multiple comparison using Tukey's test $(p<0.05)$. The software used was SAS, 9.1 version (SAS Institute, Cary, NC, USA)".

\section{RESULTS}

No significant interaction was observed between the main factors "surface protection" and "erosive challenge" $(p=0.58)$, indicating no dependent relation between them. The main factors were analyzed separately by Tukey's test.

Statistical differences were observed between the levels of "surface protection" factor $(p<0.001)$. Regardless of erosive challenge received, the glass-ionomer sealantprotected samples exhibited lower values compared with the other groups (Table 2).

Also, statistically different values were found between the erosive challenges ( $p=0.0001)$. According to the data, the average roughness after 18 DES-RE cycles was statistically greater to the one obtained after 9 DES-RE cycles and in the absence of erosion (negative control) (Table 3).

Table 2. Mean (standard deviation) of roughness data for the main factor "surface protection".

\begin{tabular}{lccc}
\hline Surface protection & Mean & Standard-deviation & Tukey \\
Absent (control) & 0.32 & 0.06 & $\mathrm{~A}$ \\
$\begin{array}{l}\text { Topical application of } \\
\text { fluoride }\end{array}$ & 0.35 & 0.05 & $\mathrm{~A}$ \\
Glass-ionomer sealant & 0.27 & 0.05 & $\mathrm{~B}$ \\
Resin sealant & 0.36 & 0.06 & $\mathrm{~A}$ \\
\hline
\end{tabular}

Distinct letters represent statistically significant differences (2-way ANOVA/Tukey, alfa $=5 \%$ ). Capital letters compare levels from the main factor surface protection. Data from erosive challenges were pooled.

Table 3. Mean (standard deviation) of roughness data for the main factor "erosive challenge".

\begin{tabular}{lccc}
\hline Erosive challenge & Mean & Standard-deviation & Tukey \\
None & 0.29 & 0.04 & $\mathrm{~b}$ \\
9 DES-RE cycles & 0.32 & 0.05 & $\mathrm{~b}$ \\
18 DES-RE cycles & 0.37 & 0.09 & $\mathrm{a}$ \\
\hline
\end{tabular}

Distinct letters represent statistically significant differences (2-way ANOVA/Tukey, alfa $=5 \%$ ). Low case letters compare levels from the main factor erosive challenge. Data from surface protection were pooled.

\section{DISCUSSION}

In addition to the teeth, erosion can affect the restorations, reducing their clinical performance and durability [4]. Rough surfaces contribute to the buildup of plaque and changes in the color of restorative material $[2,13,16]$. According to Bollen et al. [17], a threshold surface roughness value of $0.2 \mu \mathrm{m}$ is acceptable in order to avoid biofilm retention; greater values increase the risk of developing caries and periodontal disease because of biofilm accumulation. Moreover, Jones et al. [18] reported that, clinically, patients could detect surface roughness when Ra values are higher than $0.3 \mu \mathrm{m}$. Accordingly to such information, most of the surface values observed in the present investigation could be detected clinically.

In the present investigation, the use of cycles of exposure to hydrochloric acid ( $\mathrm{pH} 2.2$ ) was carried out to show a critical scenario of a patient who suffers from recurrent regurgitations that repeatedly deliver gastric content in the oral cavity [14]. Using this kind of simulation of DES-RE endogenous challenge, it was possible to see that none of the protective materials could prevent an increase in surface roughness of the nanofilled composite resin when greater aggressiveness was tested (18 cycles). Thus, the working hypothesis had to be rejected.

Composite resins basically consist of an organic matrix and inorganic particles chemically connected by a silane. Composites with higher sizes of particles have rougher surfaces than the ones that have lower fillers in their composition. The nanofilled composite tested in this investigation contains fillers $0.005-0.02 \mu \mathrm{m}$ in size, which are lower than the ones present in nanohybrid composite resins [19]. According to Munchow et al. [1], even if the chemical substances in their surroundings affect the organic matrix of the composites more actively, the type, size and concentration of inorganic fillers can influence the resistance of the material to degradation. Tantanuch et al. [19] in their study, demonstrated that nanohybrid resin showed more changes in surface roughness and erosion than the nanofilled one after cycles of immersion in white and red wine.

The degradation of the organic matrix in composite resins is caused by monomer leaching, and loss of organic substances, inorganic particles and ions [20]. The first step in this process is the absorption of water that internally diffuses through the matrix and can lead to softening and degradation, putting some properties such as the roughness of these composites at risk [21]. Despite the high hydrophobic content in the resin matrix of the nanofilled composite tested in this investigation, the presence of TEGDMA makes it sensitive to the absorption of water $[1,19]$. The increase in average roughness after 18 cycles of DES-RE in this study can be justified by changes in surface integrity of the composite during more frequent contact with acidic solutions. This degradation results in a clinically rough surface, without shine, and therefore with higher values of roughness [1,22].

Another finding of this study was that, in comparison with the other methods of surface protection, the glass-ionomer sealant showed lower averages of surface roughness. An in vitro study investigated surface roughness of restorative agents such as glass-ionomer modified by resin, nanofilled 
composite resin, conventional glass-ionomer and composite resin modified by polyacid when immersed in an acidic drink (Coca-Cola) [23]. According to the authors, the glassionomer cement modified by resin showed higher values of surface roughness compared with the tested composite resin and this fact was related to the increased size of the inorganic particles [23]. This contrast between the findings of both investigations can be explained by the different materials tested. In a glass-ionomer sealant, a different proportion of the resin matrix and glass-ionomer portion is expected, as well as reduced sizes of the particles. These factors are important in maintaining the reduced viscosity in comparison to the restorative agents, but may also explain the lower roughness. Moreover, the better the surface cover, the smaller the chance of degradation and increase in composite resin roughness, a fact that can also confirm these findings.

In a previous study, Zhou et al. [12] compared the surface roughness and microhardness of bovine enamel restored with five dental materials and exposed to erosion. They observed that enamel roughness from Clinpro XT Varnish group showed significantly lower averages compared with other types of sealants. Glass-ionomer sealant showed a longer remineralising effect, while the other materials' effects decreased with time. Apparently, these facts are related to the controlled release of fluoride, as well as the presence of calcium and phosphate that are necessary and help in the process of remineralization [12].

In this investigation, the effect of topical application of fluoride was also tested. However, this method was not able to positively influence the results. The surfaces exposed to topical application of fluoride showed similar roughness to the composite resin without any protection. In a previous study the authors observed that there was an increase in water absorption and loss of double bonds in carbon in the matrix after exposing the composite resin surfaces to acidulated phosphate fluoride, sodium fluoride and tin fluoride. Scanning electronic microscopy also showed significant changes in morphology as well as in the composition of composites treated with fluoride [24]. Changes were observed such as higher roughness, degradation of the matrix, dissolution of fillers, increasing the space between particles and the frequency of fissures [24].

Other studies carried out showed that neutral fluoride does not cause an increase in surface roughness $[10,25,26]$. This fact was related to the neutral $\mathrm{pH}$ value, which is unable to contribute to significant alterations in the topography of the surface [10]. Thus, it can be deduced that the changes observed in this investigation were derived from the absence of the protection of fluorides on the composite resin surfaces from acid challenge. The topographic changes are probably due to the contact with hydrochloric acid and not caused by the fluoride application.

Similarly, the use of the resin sealant could not change the values of surface roughness of the composite resin tested. Lopes et al. [27] investigated the effect of various sealants (Fortify, Fortify Plus and BisCover) in a nanoparticle composite similar to the one investigated in this study. The authors noticed that the sealant Fortify behaved in a similar way to the control group, concluding that it is not capable of promoting better protection for the organic matrix of nanofilled composite.

However, it is important to state that in other investigations, the resin sealant, when used as a coating, was capable of significantly reducing the enamel demineralization caused by acids and its protective effect seemed to last longer than the protective effect of rinsing solutions [11]. This fact reveals a limitation of the present investigation, since it was impossible to determine if the increase in roughness in the groups covered with resin sealant was the result of alterations in the surface of the material itself or if it was totally or partially removed, exposing the surface of the composite resin to the acids.

The findings of the present research suggest that covering the nanofilled composite could be an alternative for its protection in patients diagnosed with dental erosion. However, for the selection of the preferable material, more studies should be carried out, using complementary variables and investigating other fundamental properties of the restorative materials under erosive challenges.

\section{CONCLUSIONS}

According to the limitations of this in vitro study, glass-ionomer sealant showed a positive influence on the topography of the surface of the nanofilled composite resin; however, none of the methods could prevent an increase in roughness following exposure to aggressive cycles of endogenous DES-RE simulation.

\section{ACKNOWLEDGMENTS}

Authors thank FAPESB for financial support (RED 019/2013) and scholarship (BOL 1306/2015); and 3M-ESPE for the kind donation of materials for the present investigation.

\section{REFERENCES}

1. Munchow EA, Ferreira ACA, Machado RMM, Ramos TS, Rodrigues Junior $\mathrm{SA}$, Zanchi $\mathrm{CH}$. Effect of acidic solutions on the surface degradation of a micro-hybrid composite resin. Braz Dent J. 2014;25:321-6. https://doi. org/10.1590/0103-6440201300058

2. Soares LES, De Carvalho Filho ACB. Protective effect of fluoride varnish and fluoride gel on enamel erosion: roughness, SEM-EDS, and u-EDXRF. Microsc Res Tech. 2015;78:240-8. https://doi.org/10.1002/jemt.22467

3. Rajavardhan K, Sankar AJS, Kumar KR, Pranitha K, Kishore KK. Erosive potential of cola and orange juice on tooth colored restorative materials. Ann Med Health Sci Res. 2014;4:S208-12. https://doi.org/10.4103/21419248.141960

4. Fatima N, Abidi SYA, Qazi FUR, Jat SA. Effect of different tetra pack juices on microhardness of direct tooth colored-restorative materials. Saudi Dent J. 2013;25:29-32. https://doi.org/10.1016/j.sdentj.2012.09.002

5. Saunders JGC, Mclntyre JM. The ability of $1.23 \%$ acidulated phosphate fluoride gel to inhibit simulated endogenous erosion in tooth roots. Aust Dent J. 2005;50:263-6. https://doi.org/10.1111/j.1834-7819.2005. tb00371.x

6. Bartlett DW, Coward PY. Comparison of the erosive potential of gastric juice and a carbonated drink in vitro. J Oral Rehabil. 2001;28:1045-7. https://doi.org/10.1046/j.1365-2842.2001.00780.x

7. Soares LE, De Oliveira R, Nahórny S, Espirito Santo AM, Martin AA. Micro energy-dispersive $\mathrm{X}$-ray fluorescence mapping of enamel and dental 
materials after chemical erosion. Microsc Microanal. 2012:18:1112-7. https://doi.org/10.1017/S1431927612001535

8. Francisconi LF, Honório HM, Rios D, Magalhães AC, Machado MAAM, Buzalaf MAR. Effect of erosive $\mathrm{pH}$ cycling on different restorative materials and on enamel restored with these materials. Oper Dent. 2008:33:203-8. https://doi.org/10.2341/07-77

9. Honório HM, Rios D, Francisconi LF, Magalhães AC, Machado MA Buzalaf MA. Effect of prolonged erosive $\mathrm{pH}$ cycling on different restorative materials. J Oral Rehabil. 2008;35:947-53. https://doi.org/10.1111/j.13652842.2008.01856.x

10. Yeh ST, Wang HT, Liao HY, Su SL, Chang CC, Kao HC, et al. The roughness, microhardness, and surface analysis of nanocomposites after application of topical fluoride gels. Dent Mater. 2011;27:187-96. https:// doi.org/10.1016/j.dental.2010.10.013

11. Wegehaupt FJ, Taubock TT, Sener B, Attin T. Long-term protective effect of surface sealants against erosive wear by intrinsic and extrinsic acids. J Dent. 2012;40:416-22. https://doi.org/10.1016/j.jdent.2012.02.003

12. Zhou SL, Zhou J, Watanabe S, Watanabe K, Wen LY, Xuan K. In vitro study of the effects of fluoride-releasing dental materials on remineralization in an enamel erosion model. J Dent. 2012;40:255-63. https://doi.org/10.1016/j. jdent.2011.12.016

13. Elkassas D, Arafa A. Remineralising efficacy of different calcium-phosphate and fluoride based delivery vehicles on artificial caries like enamel lesions. J Dent. 2014;42:466-74. https://doi.org/10.1016/j.jdent.2013.12.017

14. Austin RS, Stenhagen KS, Hove LH, Dunne S, Moazzez R, Bartlett DW et al. A qualitative and quantitative investigation into the effect of fluoride formulations on enamel erosion and erosion-abrasion in vitro. J Dent. 2011;39:648-55. https://doi.org/10.1016/j.jdent.2011.07.006

15. Toda S, Featherstone JD. Effects of fluoride dentifrices on enamel lesion formation. J Dent Res. 2008:87:224-7. https://doi. org/10.1177/154405910808700303

16. Wilder AD Jr, Swift JREJ, May JRKN, Thompson JY, McDougal RA. Effect of finishing technique on the microleakage and surface texture of resinmodified glass ionomer restorative materials. J Dent. 2000;28:367-73. https://doi.org/10.1016/S0300-5712(99)00075-5

17. Bollen CML, Lambrechts P, Quirynen M. Comparison of surface roughness of oral hard materials to the threshold surface roughness for bacterial plaque retention: A review of the literature. Dent Mater. 1997;13:258-69. https://doi.org/10.1016/S0109-5641(97)80038-3
18. Jones CS, Billington RW, Pearson GJ. The in vivo perception of roughness of restorations. Br Dent J. 2004;196:42-5. https://doi.org/10.1038/ sj.bdj. 4810881

19. Tantanuch S, Kukiattrakoon B, Peerasukprasert T, Chanmanee N, Chaisomboonphun P, Rodklai A. Surface roughness and erosion of nanohybrid and nanofilled resin composites after immersion in red and white wine. J Conserv Dent. 2016;19:51-5. https://doi.org/10.4103/0972 0707.173199

20. Bagheri R, Tyas MJ, Burrow MF. Subsurface degradation of resin-based composites. Dent Mater. 2007:23:944-51. https://doi.org/10.1016/j. dental.2006.06.035

21. Cilli R, Pereira JC, Prakki A. Properties of dental resins submitted to $\mathrm{pH}$ catalyzed hydrolysis. J Dent. 2012;40:1144-50. https://doi.org/10.1016/j. jdent.2012.09.012

22. Abu-bakr N, Han L, Okamoto A, Iwaku M. Changes in the mechanical properties and surface texture of compomer immersed in various media. J Prosthet Dent 2000:84:444-52. https://doi.org/10.1067/mpr.2000.109635

23. Bajwa NK, Pathak $A$. Change in surface roughness of esthetic restorative materials after exposure to different immersion regimes in a cola drink ISRN Dent. 2014; [cited 2014 March 23]. Available at: https://www. hindawi. com/journals/isrn/2014/353926/

24. Papagiannoulis L, Tzoutzas J, Eliades G. Effect of topical fluoride agents on the morphologic characteristics and composition of resin composite restorative materials. J Prosthet Dent. 1997:77:405-13. https://doi. org/10.1016/S0022-3913(97)70166-5

25. el-Badrawy WAG, McComb D, Wood RE. Effect of home-use fluoride gels on glass ionomer and composite restorations. Dent Mater. 1993;9:63-7. https://doi.org/10.1016/0109-5641(93)90108-3

26. Dionysopoulos P, Gerasimou P, Tolidis K. The effect of home-use fluoride gels on glass-ionomer, compomer and composite resin restorations. J Oral Rehabil. 2003;30(7):683-9. https://doi.org/10.1046/j.13652842.2003.01104.x

27. Lopes MB, Saquy PC, Moura SK, Wang L, Graciano FMO, Correr Sobrinho $L$, et al. Effect of different surface penetrating sealants on the roughness of a nanofiller composite resin. Braz Dent. J 2012;23:692-7. https://doi. org/10.1590/S0103-64402012000600011 